\title{
Impact of Record Keeping Practices on Business Performance of Small and Medium Scale Enterprises in Sri Lanka
}

\author{
Saseela Balagobei \\ Senior Lecturer, Department of Financial Management, University of Jaffna, Sri Lanka \\ E-mail: saseelab@univ@jfn.ac.lk
}

Received: November 24, 2019 Accepted: December 18, 2019 Published: December 29, 2019

doi:10.5296/ijafr.v9i4.15897

URL: https://doi.org/10.5296/ijafr.v9i4.15897

\begin{abstract}
Record keeping plays a vital role in development by providing recorded information which is crucial in the strategic formulation of national development policies and plans. The purpose of the study is to examine the influence of record keeping practices on the business performance of small and medium scale enterprises in Sri Lanka. Record keeping practices consists of proper accounting records, preparation of accounting records and accounting records procedures whereas business performance is measured by organizational goal achievement, organizational effectiveness and organizational efficiency records. A structured questionnaire was used to collect the primary data from 75 SMEs which were selected by means of the random sampling technique. The results reveal that record keeping practices have significant positive influence on business performance of Small and medium enterprises in Sri Lanka. It can be recommended that academic institutions and other bodies which are responsible for SMEs should organize training programmes for those operators who do not have the technical knowhow in the field of accounting to come to grips with it and also provide some SME-specific accounting guidelines and template forms for capturing accounting practices for the operators to use.
\end{abstract}

Keywords: Business performance, Organizational effectiveness, Organizational efficiency, Record keeping practices

JEL: M41 


\section{Introduction}

Record keeping is the recording of business transactions in systematic manner so that the financial position of an organization can be ascertained at any point in time. It has become the foundation on which modern businesses depends. Small and medium enterprises (SMEs) have been identified as an important strategic sector for promoting growth and social development of Sri Lanka. Over the years, SMEs have gained wide recognition as a major source of employment, income generation, poverty alleviation and regional development. The SMEs cover broad areas of economic activity such as agriculture, mining, manufacturing, construction and service sector industries.

Accounting plays a key role in the success or failure of contemporary business organizations. It foils the exploitation of assets, increases production and yield, controls expenses and helps to improve the efficiency of the overall management. The role of management is vital in the whole development of a business organization. Accounting systems are responsible for recording, analyzing, monitoring and evaluating the financial condition of the firms, preparing documents necessary for tax purposes, providing information support to many others organizational functions. Accounting systems provide a source of information to owners and managers of SMEs operating in any industry for the use in measuring financial performance (Maseko \& Manyani, 2011).

According to Ademola et al. (2012), record keeping is essential to business management. Record keeping involves identification, classification, storage and protection, receipt and transmission, retention and disposal of records for preparation of financial statements. Ikechukwu (1993) refers that keeping records is crucial for the successful performance of a business. A comprehensive record keeping system makes it possible for entrepreneurs to develop accurate and timely financial reports that show the progress and current condition of the business. With the financial report generated from a good recordkeeping system, performance during one period of time with another period can be compared. An accurate record of the business' financial performance is vehicle to monitor performance in specific areas

Today's accounting focuses on providing appropriate, reliable and timely financial information to decision makers, who use the information for the effective financial decisions concerning their business entities. "Accounting" according to business dictionary can be defined as a systematic procedure that identify, record, measure, classify, verify, summarize, interprets, and communicate financial facts. It reveals profit or loss for a given period, and the value and nature of a firm's assets and liabilities and owner's equity. It involves ascertainment, recording, summarizing, and reporting of financial information used in evaluating and monitoring a firm's economic undertakings. An accounting system, therefore, is an organized set of manual and computerized accounting methodology, processes, and wheels which are used in gathering, recording, classifying, analyzing, summarizing, interpreting, and presenting accurate and timely financial information for decision making in an organization. 


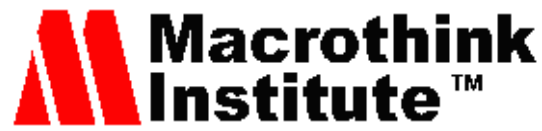

International Journal of Accounting and Financial Reporting

ISSN 2162-3082

2019, Vol. 9, No. 4

The importance of financial performance measurement to any business entity, big or small, cannot be over-emphasized. In any sense, profit can analogously be viewed as the life-blood of a business and hence the accounting bases, concepts and principles adopted ought to capture and report all the relevant accounting information to ensure reliability in its measurement. Reported profits reflect changes in wealth of owners and this can explain why major economic decisions in business are centered on financial performance as measured by profitability (Cooley and Edwards, 1983). It has been recognized that appropriate accounting information is important for a successful management of any business entity, whether large or small (European Commission, 2008).

It is crucial therefore that record keeping practices of SMEs supply complete and relevant financial information needed to improve economic decisions made by entrepreneurs. This research therefore focuses on investigating the record keeping practices followed by SMEs, their completeness and the availability of accounting skills and knowledge to capture and process accounting information which can be used to measure business performance in SMEs.

The accounting tools such as the cost accounting system, the financial accounting practices and even the management accounting practices provide information on the performance and other useful information about the entity to the various users. The objective of financial statements is to provide information about the financial position, performance and changes in financial position of an enterprise that is useful to a wide range of users in making economic decisions. Similarly, accounting practice is the system of procedures and controls that an accounting department uses to create and record business transactions. Accounting practice should ideally be extremely consistent, since there are many business transactions that must be dealt with in exactly the same manner in order to produce consistently reliable financial statements.

The development of SME sector is of paramount important for any country irrespective of their level of development, since this sector has great potential to generate maximum socio economic benefits to the country with minimum level of investment. Small and Medium Scale Enterprises (SMEs) make up 80 per cent of all businesses about 20 percent of industrial establishments. In the service sector SMEs accounts for more than 90 percent of business establishments and are estimated to contribute about 35 percent of employment. The SMEs play an important role in promoting inclusive growth in a country.

There are few studies conducted on accounting record keeping practices of small and medium enterprises in Sri Lanka. These studies conducted have not shown that how record keeping practices improve the business performance of SMEs in Sri Lanka. Therefore this study attempts to investigate the effect of record keeping practices on business performance of Small and Medium Scale Enterprises in Sri Lanka

The problems of SMEs failure is poor management ability which includes accounting problem-solving. Small and medium enterprise experiences difficulties in raising equity capital from the finance houses or individuals. Even when the finance house agrees to provide equity capital, the conditions are always dreadful. All these result to inadequate 
capital available to the sector and thus lead to poor financing. Another problems facing SMES is Lack of competent management which is the consequence of inability of owners to employ the services of experts; Use of obsolete equipment and methods of production because of owner's inability to access new technology; Excessive competition which resulted from sales which is a consequence of poor finance to cope with increased competition in the industry; The high cost of available raw materials affects the prices of good food. This only has adverse effect on the turnover of the enterprise but also on the profitability; The availability of infrastructural facilities is grossly inadequate in the areas of access roads, electricity, water supply, etc. and Multiplicity of policies and regulatory measures such as removal of fuel subsidy, taxes, several charges on loans.

Although SMEs role in the economy is substantial, many of them face challenges and problems. There are many failures of SMEs in Sri Lanka and the Central Bank of Sri Lanka (1998) stated that inadequate capital, inadequate institutional credit facilities, improper accounting techniques and etc. The inability of SMEs to find their counter funds requirement as a condition of financial arrangements creates another barrier for SMEs to enjoy the facilities offered in concessionary finances (Abeygunasekera \& Fonseka 2012). However, poor recordkeeping, inefficient use of accounting information to support their financial decision making and the low quality and reliability of financial data are part of the main problems of SMEs (Karunananda \& Jayamaha, 2011).

The place of sound accounting and internal control systems in any business, irrespective of its scale, cannot be overemphasized. A vast majority of small-scale businesses cannot afford the complexity of a detailed accounting system even if they would have. Hence, the existence of single entries in their books and in some cases incomplete records (Onaolapo, et al., 2011). Audits of small and medium scale enterprises have proven to be among the most worrisome for professional accountants because of the inadequacy of the internal controls. Except for statutory demands, small and medium scale enterprises hardly give serious thoughts to the process of sound accounting, yet the inadequacy and ineffectiveness of accounting processes have been responsible for untimely collapse of a host of them (Mukaila \& Adeyemi, 2011). Based on the problem, the following research question is formulated, to what extent record keeping practices influence the business performance in Sri Lanka?

Accounting information is fruitful in important activities as: the evaluation of enterprises' position in terms profitability, liquidity, activity and leverage; measurement of performance; and assessment of the profitability of alternative courses of action. The objective is to investigate the impact of record keeping practices on business performance of Small and Medium Enterprises in Sri Lanka.

\section{Literature Review}

There have been some studies that link record keeping and business performance of organisation. For instance, Aladejebi and Oladimeji (2019) analyse the extent to which accounting information is being used to measure the financial performance of SMEs. Questionnaires were administered to 200 SMEs owners out of which 197 questionnaire were valid and analysed using Likert scale. It was observed that while respondents agree that major 
benefits of keeping proper records is to know the performance of the business and that record keeping is key to the success of the business, majority of the SMEs owners lack basic accounting knowledge and decry the cost involved in preparing financial statement hence they keep the records themselves manually.

Nassiuma (2019) explored a positive influence of record keeping practices on the performance of SMEs. Further it concluded that in order for SMEs to perform, there has to be an investment on financial management practices particularly financial reporting and analysis by stakeholders' especially financial institutions. Mwebesa , Kansiime , Asiimwe, Mugambe and Rwego. (2018) revealed that 67 (67.7\%) knew the type of financial books recognized by international accounting standards board (IASB). 36 (36.4\%) respondents reported keeping money in boxes while $22(22.2 \%)$ kept money in the bank. Findings revealed a significant positive relationship between the financial record keeping and financial performance $\left(\mathrm{r}=0.297^{* *}, \mathrm{P}>0.05\right)$. Notwithstanding the above findings, there is need to train group leaders in financial recordkeeping

Adurayemi (2016) analysed the effects of financial record keeping on the performance of small and medium scale enterprises in Nigeria using descriptive method of research with questionnaires being distributed, analysed and interpreted to know the minds of SME owners in keeping financial records of their daily transactions. It was found out that there was positive relationship between financial record keeping and SMEs performance in Nigeria. Onaolapo and Adegbite (2014) investigated the impact of accounting records on SMEs' performance. Data were collected through interviews and questionnaires from a sample of 113 SMEs using a mixture of stratified and purposive sampling techniques. Descriptive statistics, Chi-square and analysis of variance (ANOVA) were used for data analysis. The findings of the study revealed that there is a strong positive relationship between accounting records keeping and SMEs' performance.

Yousef (2013) carried out a research on the use of accounting information by SMEs in the south district of Jordan. Data were systematically collected using questionnaires from a sample of 136 SMEs. The study found out that the level of awareness on the importance of financial management and accounting information is still very low among SMEs in the south district of Jordan. Amaoko (2013) studied the accounting practices of SMEs in the Kumasi metropolis of Ghana. The study was based on data collected through structured questionnaires from a sample of 210 SMEs. The study found that majority of SMEs fail to keep proper accounting records as they feel that it is not necessary; it exposes their financial position; it is time consuming; and expensive. This study reaches the same conclusion with the study of Yousef (2013) "that the level of awareness among SMEs on the importance of proper accounting record keeping is still very low." Ohachosim, Onwuchekwa and Ifeanyi (2012) in their study titled "Financial Challenges of Small and Medium-Sized Enterprises (SMEs) In Nigeria: The Relevance of Accounting Information" carried out a survey of 348 SMEs in Anambra State. Structured questionnaire were used in data collection. Analysis was by means of ordinary least square (OLS) and they found out that poor accounting system is what characterizes most SMEs in Nigeria. 
Maseko and Manyani (2011) studied accounting practices of SMEs in Zimbabwe using Bindura as a case study. Data were gotten from a survey of 100 SMEs through the administration of structured questionnaires. The findings of the study revealed that majority of SMEs do not keep accounting records due to lack of accounting knowledge. They recommended that the national authorities should develop accounting guidelines for SMEs and undertake programmes for train entrepreneurs of small businesses in accounting. SMEs will contribute, in no small measure, to their performance. In their recommendation, they advised SMEs to consult accountants regularly so that they can be able to maintain high and generally accepted accounting practices.

Tuanmat and Smith (2011) show that the level of changes in management accounting practices increased over the five year period from 2003 to 2007. The changes mostly occurred through the introduction of new practices, replacement of existing practices and modification of the way existing practices were used. Further it reveals that there are no significant differences in management accounting practices among local and foreign companies, or between small and medium, and large companies. Tzempelikos and Gounaris (2015) identify a set of key account management practices at the strategic, organizational, tactical and control levels of management and provide support for most of the hypothesized relationships, showing that the identified practices positively affect performance and dyadic outcomes through the mediation coming from the variables examined. From a theoretical perspective, the study adds to understanding of the factors underlying effective Key account management practices.

Many researchers have studies about SMEs, focusing on different study problems such as; management, accounting and financial needs and challenges, causes of small business failures. Few researchers investigated about the contribution of accounting records to the performance of SMEs. They have pointed out that, some SMEs produce accounting records based on computerized packages, relying on accountants but often they left the complexity of information, accounting records hinder application of appropriate measures in evaluating business success. Moreover, among the studies, few studies are done in Tanzania. Therefore the study seeks to cover this gap.

\section{Methodology}

The methodology carried out to achieve the said objective of the study explains independent and dependent variables used and operationalization of those variables. Further it discusses the method adopted for the sample selection and data extraction.

Determining the population of SMEs in Sri Lanka is imprecise. All the existing data sources lack accuracy and complete coverage of the sector wise SMEs in spite of various government and semi-government institutions engaged in compiling SME related databases. Thus there is no centralized database available representing wide spectrum of areas that SMEs are operating like manufacturing, agriculture, mining, construction, service etc. There are 144 SMEs which are registered in Sri Lanka Chamber of Small and medium industries. Data was collected from 75 SME which were selected by means of the random sampling technique. 150 questionnaires were issued. A pilot test was performed. 


\section{Mll Macrothink}

International Journal of Accounting and Financial Reporting

ISSN 2162-3082

2019, Vol. 9, No. 4

Primary data was obtained from the selected SMEs using structured questionnaires. The questionnaire has two sections: sections A and B. Section A consists of the questions related to personal information of respondents for the research and section $B$ evaluate the degree of the agreement with the impacts of record keeping practices on business performance. The respondents were requested to indicate the extent of their agreement with a series of questions on a five-point Likert scale. The collected data was analyzed by using Statistical software for social science (SPSS 21).

Record keeping is independent variable measured by proper accounting records, preparation of accounting records and accounting records procedures whereas the dependent variable, business performance consists of organizational goal achievement, organizational effectiveness and organizational efficiency records

\section{Data Analysis and Discussion}

In order to achieve the objective, the data collated through the survey are presented and analyzed. The study focused entirely on SMEs sector mainly consists of seventy five manufacturing, trading and beverage food and tobacco enterprises. Descriptive statistics are applied to investigate and describe the business characteristics of SMEs, adoptability of record keeping practices to develop a general view about the sample of the study.

In pilot testing, validity and reliability were conducted to measure that questionnaire are valid and reliable to be used in this research. According to Hair et al (1998), validity is "extent to which a measure or set of measures correctly represents the concept of study - the degree to which it is free from any systematic or nonrandom error. Validity is concerned with how well the concept is defined by the measure(s)." Validity in this pilot testing is calculated. The result is valid and all the item questions are valid and can be used in this study.

According to Hair et al (1998), reliability is "extent to which a variable or set of variables is consistent in what it is intended to measure." The questionnaire on this study calculated reliability by using SPSS software with Cronbach's alpha method. The result will be stated as reliable if the value of Cronbach's alpha value is greater than 0.60. Thus the internal consistency of different record keeping practices and business performance of this study were tested through Cronbach alpha coefficient.

Table 1. Testing the reliability

\begin{tabular}{llll}
\hline Variables & Number of items & Cronbach's Alpha \\
\hline $\begin{array}{l}\text { Record } \\
\text { keeping }\end{array}$ & Proper accounting records & 8 & 0.723 \\
\cline { 2 - 4 } & Preparation of accounting records & 3 & 0.688 \\
\cline { 2 - 4 } & Accounting records procedures & 3 & 0.621 \\
\hline Business performance & 6 & 0.648
\end{tabular}




\section{Macrothink}

International Journal of Accounting and Financial Reporting

ISSN 2162-3082

2019, Vol. 9, No. 4

Results show that the Cronbach's alpha coefficient for each record keeping practice and business performance exceeds the commonly accepted criterion of 0.6. All selected record keeping practices hold significant reliability test values. Therefore, the data gathered from selected record keeping practices of SMEs related questionnaires were considered as the reliable data.

The exploration of record keeping practices and business performance in this study includes the male-female distinction, education background, size of the business, legal form and number of years in operations of the current business. These characteristics help to understand the nature of the small and medium enterprises in Sri Lankan context with reference to the selected sample of the study. Table 2 represents summary of descriptive statistics pertaining to different demographic and business characteristics of the selected sample of SMEs.

Table 2. Demographic and Business characteristics of the selected sample of SMEs

\begin{tabular}{|c|c|c|}
\hline Demographic Characteristics & Frequency & Percentage \\
\hline \multicolumn{3}{|l|}{ Gender: } \\
\hline Male & 72 & $96 \%$ \\
\hline Female & 03 & $4 \%$ \\
\hline \multicolumn{3}{|l|}{ Position of the Business: } \\
\hline Owner is separate from the manager & 54 & $72 \%$ \\
\hline Both Owner \& Manager is one individual & 21 & $28 \%$ \\
\hline \multicolumn{3}{|l|}{ Number of years in operations of the current business: } \\
\hline Up to 05 & 21 & $28 \%$ \\
\hline 05 to 10 & 21 & $28 \%$ \\
\hline Over 10 & 33 & $44 \%$ \\
\hline
\end{tabular}

Education:

$\begin{array}{lll}\text { School level } & 52 & 69.33 \% \\ \text { Graduate level } & 15 & 20 \% \\ \text { Professional level } & 08 & 10.64 \%\end{array}$

Size of the business:

$\begin{array}{lll}\text { Small } & 50 & 66.66 \% \\ \text { Medium } & 25 & 33.34 \%\end{array}$

Legal Form:

Sole-proprietorship

Limited Company
48

27
$64 \%$

$36 \%$ 


\section{Mll Macrothink}

International Journal of Accounting and Financial Reporting

ISSN 2162-3082

2019, Vol. 9, No. 4

With regard to the male-female distinction, majority of the business owners are male and it represented $96 \%$ of the sample, thus showing male dominance in the ownership of SMEs. With respect to the management of entities it was noted that around $28 \%$ of businesses are managed by the owners whereas the rest of the organizations are managed by a manager who is not an owner of the business.

The majority of SMEs have been conducting its operations more than five years $(72 \%)$. Further qualifications of owners revealed that more than $69 \%$ of the SME owners possess School level education. However, the level of professional achievements and qualifications of owners were at a low level. The classification between small and medium businesses revealed that more than $33 \%$ entities satisfied the criteria to be considered them as medium size businesses. From the legal form of SMEs' perspective, it was revealed that more than $64 \%$ of SMEs are sole-proprietorship.

Multicollinearity is a phenomenon in which two or more independent variables are highly correlated with each other. Multicollinearity refers to the successive inclusion of additional variables that lift the collinearity of the full set of explanatory variables to a 'harmful' level (Lauridsen and Mur, 2006).

Table 3. Multicollinearity

\begin{tabular}{lll}
\hline \multirow{2}{*}{ Model } & \multicolumn{2}{l}{ Collinearity Statistics } \\
\cline { 2 - 3 } & Tolerance & VIF \\
\hline Proper accounting records & .876 & 1.345 \\
\hline Preparation of accounting records & .987 & 1.567 \\
\hline Accounting records procedures & .854 & 1.234 \\
\hline
\end{tabular}

Variance inflation factor is a method used to study the multicollinearity using SPSS and, if the variance inflation factor is greater than 10 , which is a clear case of multicollinearity (Hair et al., 1995). In this study multicollinearity problem don't arise among the variables as all variance inflation factors are less than 10 .

Correlation provides a simple tool for examination of the relationship between two variables. It constitutes an invaluable initial analysis and a building block for further analysis. In accordance with the correlation matrix represented in table 04, proper accounting records, preparation of accounting records and accounting records procedures have a significant relationship with business performance at 5\% levels $\left(\mathrm{r}=.578^{*}, \mathrm{P}<0.05 ; \mathrm{r}=.768^{*}, \mathrm{P}<\right.$ 0.05 and $\mathrm{r}=.725^{*}, \mathrm{P}<0.05$ ) respectively. Therefore there is a significant positive relationship between record keeping practices and business performance of small and medium scale enterprises in Sri Lanka. 
Table 4. Correlations matrix for record keeping practices and Business performance
(1)
(2)
(3)
(4)

\begin{tabular}{|c|c|c|c|c|c|}
\hline \multirow{2}{*}{$\begin{array}{l}\text { (1) Proper } \\
\text { records }\end{array}$} & $\begin{array}{l}\text { Pearson } \\
\text { Correlation }\end{array}$ & \multicolumn{4}{|l|}{1} \\
\hline & Sig. (2-tailed) & & & & \\
\hline \multirow{2}{*}{$\begin{array}{l}\text { (2) Preparation } \\
\text { accounting records }\end{array}$} & $\begin{array}{l}\text { Pearson } \\
\text { Correlation }\end{array}$ & .233 & 1 & & \\
\hline & Sig. (2-tailed) & .982 & & & \\
\hline \multirow{2}{*}{$\begin{array}{l}\text { (3) Accounting } \\
\text { procedures }\end{array}$} & $\begin{array}{l}\text { Pearson } \\
\text { Correlation }\end{array}$ & .362 & .452 & 1 & \\
\hline & Sig. (2-tailed) & .756 & .567 & & \\
\hline \multirow[t]{2}{*}{ (4) Business performance } & $\begin{array}{l}\text { Pearson } \\
\text { Correlation }\end{array}$ & $.578^{*}$ & $.768^{*}$ & $.725^{*}$ & 1 \\
\hline & Sig. (2-tailed) & .042 & .038 & .048 & \\
\hline
\end{tabular}

**. Correlation is significant at the 0.01 level (2-tailed).

Regression Analysis table 05 represents the results of multiple regression analysis to examine the impact of record keeping practices and business performance of Small and medium enterprises in Sri Lanka.

Table 5. Regression coefficients for Record keeping practices and Business performance

\begin{tabular}{|c|c|c|c|c|c|}
\hline \multicolumn{2}{|c|}{ Model } & \multirow{2}{*}{$\begin{array}{l}\text { B } \\
5.447\end{array}$} & \multirow{2}{*}{$\begin{array}{l}\text { Std. Error } \\
.632\end{array}$} & \multirow{2}{*}{$\frac{t}{6.433}$} & \multirow{2}{*}{$\begin{array}{r}\mathrm{t} \mathrm{Sig} \\
.000\end{array}$} \\
\hline & (Constant) & & & & \\
\hline \multirow{3}{*}{1} & Proper accounting records & .334 & .243 & 1.432 & .034 \\
\hline & Budgeting practices & .589 & .154 & 1.043 & .046 \\
\hline & Payroll Accounting & .526 & .164 & 1.234 & .048 \\
\hline
\end{tabular}

Adjusted $\mathrm{R}^{2}-0.648 \quad$ F value $-3.543(\mathrm{P}=0.05)$

As shown in Table 5 proper accounting records, preparation of accounting records and accounting records procedures have a significant influence on business performance at 0.05 levels $(\beta=.334, \mathrm{P}<0.05 ; \beta=.589, \mathrm{P}<0.05$ and $\beta=.526, \mathrm{P}<0.05)$ respectively. Therefore it can be concluded that record keeping practices have a significant positive influence on business performance. This finding is collaborated with previous study of Onaolapo and Adegbite (2014). 
Since the adjusted $\mathrm{R}^{2}$ Value for record keeping practices and business performance is 0.648 . This represents that $64.8 \%$ percent of the variance in business performance is explained by record keeping practices such as proper accounting records, preparation of accounting records and accounting records procedures and the remaining $35.2 \%$ of the variance is not depicted in this model. As $\mathrm{F}$ value is $3.543(\mathrm{P}=0.05)$ in this analysis the regression model is more applicable for this study.

\section{Conclusion and Recommendation}

This study was designed for exploring the extent of use of record keeping practices among SMEs Sri Lanka and to find if there is any significant influence on business performance. This study mainly focus on Small and medium enterprises in Sri Lanka and seventy five small and medium enterprises have been selected as sample while Pearson's correlation and multiple regression analysis have been performed to investigate the influence of record keeping practices on business performance. The findings of this study reveals that record keeping practices have significant positive influence on business performance of Small and medium enterprises in Sri Lanka.

It can be recommended that academic institutions and other bodies which are responsible for SMEs should organize training programmes for those operators who do not have the technical knowhow in the field of accounting to come to grips with it and also provide some SME-specific accounting guidelines and template forms for capturing accounting practices for the operators to use. The study recommends that SMEs operators should endeavor to keep proper records and where necessary seek the services of SME professionals to do so at minimal cost because the cost involved in business failure as a result of lack of proper record keeping far outweigh the cost of good record keeping for a business concern. The study recommends that SMEs operators should seek for basic accounting knowledge to enable them maintain some records properly and where possible engage the services of SMEs Professionals who will be able to keep proper record and prepare relevant financial report at a minimal cost for the business, banks and for other third party usage.

\section{Limitations and Future Direction for the Study}

The study has the following limitations,

- Owners of small scale business units were not willing to give their confidential information which was sufficient to the researcher.

- There were issues of non-response errors among respondents and this was overcome by increasing on the sample size.

- There were time limitations and incompleteness. The targeted members as participants of the study were busy people whose time and availability were highly constrained.

Further research need to be carried out on the effect of accounting practices on performance of small scale with economic conditions. Further this study has considered the quantitative approach. Future research can focus on qualitative study to collect the primary data by using structured interview, focus group discussion, etc. 


\section{References}

Abeygunasekera, A. W. J. C., \& Fonseka, A. T. (2012). Non-compliance with standard accounting practices by small and medium scale enterprises in Sri Lanka. Postgraduate Institute of Management, University of Sri Jayawardenepura, Sri Lanka.

Ademola, G. O., Samuel O. J., \& Ifedolapo O. (2012). The Roles of Record Keeping In the Survival and Growth of Small Scale Enterprises in Ijumu Local Government Area of Kogi State. Global Journal of Management and Business Research, 12(13).

Adurayemi, A. (2016). Financial Record Keeping and Small \& Medium Enterprises Performance in Nigeria. International Journal of Social Relevance \& Concern, 4(1).

Aladejebi, O., \& Oladimeji, J. (2019). The Impact of Record Keeping On the Performance of Selected Small and Medium Enterprises in Lagos Metropolis. Journal of Small Business and Entrepreneurship Development, 7(1), 28-40.

Amaoko, G. B. (2013). Accounting practices of SMEs: A case study of Kumasi metropolis in Ghana. International Journal of Business and Management, 8(24), 73-83.

Asika, N. (1991). Research methodology in the behavioural sciences. Lagos: Longman Nigeria Plc.

Cooley, P., \& Edwards, C. (1983). Financial objectives of small firms. American Journal of Small Business, 8(1), 28-31.

George, D., \& Mallery, P. (2003). SPSS for Windows step by step: A simple guide and reference, 11.0 update (4th ed.). Boston, MA: Allyn \& Bacon

Hair, J. F., Black, W. C., Babin, B. J., Anderson, R. E., \& Tatham, R. L. (1998). Multivariate Data Analysis, 5(3), 207-219. Upper Saddle River, NJ: Prentice hall.

Ikechukwu C. (1993). Success Key Point Book Keeping and Accounts. Onitsha: Hybrid Publisher Limited.

Karunananda, A., \& Jayamaha, A. (2011). Financial practices and performance of small and medium-size enterprises in Sri Lanka. Proceedings of International Conference on Business \& Information.

Lauridsen, J., \& Mur, J. (2006). Multicollinearity in cross-sectional regressions. Journal of Geographical Systems, 8(4), 317-333.

Maseko, N., \& Manyani, O. (2011). Accounting Practices of SMEs in Zimbambwe. Journal of Accounting and Taxation, 3(8), 171-181.

Mwebesa, L. C. K., Kansiime, C., Asiimwe, B., Mugambe., \& Rwego, I. (2018). The Effect of Financial Record Keeping on Financial Performance of Development Groups in Rural Areas of Western Uganda. International Journal of Economics and Finance, 10(4). 


\section{Ml Macrothink}

International Journal of Accounting and Financial Reporting

ISSN 2162-3082

2019, Vol. 9, No. 4

Nassiuma, B. (2019). Relationship between Record Keeping practices and Performance of Small and Medium Enterprises in Uasin Gishu County. Open Journal of Economics and Commerce, 2(1), 34-40.

Ohachosim, C. I., Onwuchekwa, F. C., \& Ifeanyi, T. T. (2012). Financial challenges of Small and Medium-Sized Enterprises (SMEs) in Nigeria, The Relevance of Accounting Information. Review of Public Administration and Management, 1(2), 77-99.

Onaolapo, A. A., Fasina, H. T., Opoola, N. A., \& Olatunji, A. (2011). Basic Accounting One. Ogbomosho: Johnny Printing Works.

Onaolapo, A., \& Adegbite, I. (2014). The Analysis of the Impact of Accounting Records Keeping on the Performance of Small Scale Enterprises. International Journal of Academic Research in Business and Social Sciences.

Tuanmat, T. Z., \& Smith, M. (2011). Changes in management accounting practices in Malaysia. Asian Review of Accounting, 19(3), 221-242.

Tzempelikos, N., \& Gounaris, S. (2015). Linking key account management practices to performance outcomes. Industrial Marketing Management, 45, 22-34.

Yousef, B. (2013). The use of accounting information by Small and medium enterprises in south district of Jordan (An empirical study). Research Journal of Finance and Accounting, $4(6), 169-175$.

\section{Copyright Disclaimer}

Copyright for this article is retained by the author(s), with first publication rights granted to the journal.

This is an open-access article distributed under the terms and conditions of the Creative Commons Attribution license (http://creativecommons.org/licenses/by/4.0/) 